\title{
Cassava (Manihot esculenta Crantz) Production Constraints, Farmers' Preference Criteria and Diversity Management in Togo
}

\author{
K. Kombate ${ }^{1,2}$, I. Dossou-Aminon ${ }^{1,3} *$, A. Dansi ${ }^{1,3}$, R.A. Adjatin ${ }^{1,3}$, G.A. Dassou ${ }^{1,3}$, K. \\ Kpemoua $^{2}$, M. Dansi ${ }^{1,3}$, K. Akpagana ${ }^{4}$ and A. Sanni ${ }^{5}$
}

${ }^{1}$ Laboratory of Biotechnology, Genetic Resources and Plant and Animal Breeding (BIORAVE),

Faculty of Sciences and Technology of Dassa, P.O. Box 143, Dassa- Zoumè, Benin

${ }^{2}$ Institut Togolais de Recherche Agronomique (ITRA), 01 B.P. 1163 Lomé 01, Togo

${ }^{3}$ Institut de Recherche, de Formation et de Développement sur les Plantes Cultivées, les

Animaux d'Elevage et les Plantes Médicinales (IRDCAM), 071 BP28, Cotonou, Benin

${ }^{4}$ Laboratoire de Botanique et d'Ecologie Végétale, Faculté des Sciences (FS) Université de Lomé

01 BP 1515, Lomé 01, Togo

${ }^{5}$ Laboratory of Biochemistry and Molecular Biology, Faculty of Sciences and Technology

(FAST), University of Abomey-Calavi (UAC), P.O. Box 526 Cotonou, Benin

*Corresponding author

\section{A B S T R A C T}

\begin{tabular}{|l|}
\hline Ke y w o r d s \\
Cassava, \\
constraints, \\
preference \\
criteria, \\
diversity \\
management, \\
Togo \\
\hline Article Info \\
\hline $\begin{array}{l}\text { Accepted: } \\
\text { 03 April } 2017 \\
\text { Available Online: } \\
\text { 10 June } 2017\end{array}$ \\
\hline
\end{tabular}

Cassava (Manihot esculenta Crantz) is among the main food crops of Togo. In the country's traditional agriculture, a great diversity a varieties exist and need to be preserved. Moreover, the production constraints that can be solved through breeding of novel varieties and the farmers' varietal preference criteria are not yet well documented. To fill these gaps of knowledge a survey was conducted in 40 villages distributed throughout the country using participatory approach (individual survey and group discussion with questionnaire). The first 5 most important constraints at national level were: the attacks of insects, low marketable value of cassava roots, leaves and stem diseases (mainly viruses and bacterial diseases), and root rots. The most important varieties preference criteria were high productivity, early maturity, the good poundability, resistance to diseases, good quality of gari and good in ground post maturity conservation. The number of varieties maintained per household varies from 1 to 8 with 2 in average. No seed is used as planting material. The crop is propagated only by stem cuttings and the farmers' knowledge on the floral biology, diseases and their propagation, the use of botanical seeds to generate plantlet, the contribution of the reproductive biology to the enhancement of the existing diversity and to the development of new cultivars is very low. No strategy is put in place for the preservation of the diversity and its sustainable use. The study recommends intensive education and sensitization of the farmers as well as their organization for cassava biodiversity conservation in Togo.

\section{Introduction}

Originated from Amazonia where it was domesticated (Santos et al., 2013), Cassava (Manihot esculenta Crantz) is the main staple food for more than 800 million of people worldwide (Bull et al., 2011; De Oliveira et al., 2014). Cassava is valued as food-bank 
stored in the ground (Lebot et al., 2015). It is the third largest source of carbohydrates for human food in the world especially in Africa (Jarvis et al., 2012; Lekha et al., 2011), it's largest center of production. It is cultivated mainly by resource-limited small farmers for its starchy roots, which are used as human food either fresh or in many processed forms and products and for animal feed (Carpenter, 2011; Zawedde et al., 2014).

In traditional agroecosystems in Africa and elsewhere, farmers generally grow a large diversity of landraces per crop species that need to be conserved as its sustainable utilization may help to lower the risk of crop failure owing to vagaries of climate, diseases, pests and soil limitations (Willemen et al., 2007; Yong-Bi et al., 2014).

Sustainable management of genetic resources is a crucial issue in the global context of food security and on-farm conservation is now widely acknowledged as a relevant strategy to reach this goal (Thomas et al., 2011). Seed. Locally adapted landraces usually produce lower yields during optimal conditions than "improved" cultivars, but the relative stability of their yields provides food security to households (Dossou-Aminon et al., 2016; Kombo et al., 2012; Yong'an et al., 2010). In Togo a relatively important diversity of cassava local varieties exists (Kombate et al., 2017) but its local management and the farmers' varietal preference criteria are still not yet properly documented for use by the breeders and conservationists. The productions constraints and their variation across production zones are also not well known for priority setting.

The development of cassava production in Togo will require the use of modern cultivars resistant to pests and diseases that are better adapted to climate change and have producers and consumers' qualities. In this context, the development of a breeding program that will lead to adoptable cultivars cannot be done without the knowledge of the production constraints and farmers' preference criteria. We report in this paper the results of an ethnobotanical survey conducted on cassava in Togo in order to:

- Document the productions constraints and their variation across production zones

- Identify and prioritize farmers' preference criteria

- Understand the traditional management of cassava diversity at community level for development of conservation strategies

\section{Materials and methods}

\section{Study area and sites selection}

With $56,600 \mathrm{~km}^{2}$ of land area, Togo is located in West Africa between Burkina Faso (in the North), Ghana (in the West), Benin (in the East) and the Atlantic Ocean (in the South). The country has slightly more than 6191155 habitants organized around 41 ethnic groups and unequally distributed throughout five administrative regions (DGSCN, 2011). Apart from the Savanna administrative region, cassava is grown almost everywhere in Togo (Country STAT, 2014).

To document the production constraints and farmers' preference criteria, 40 villages located in four administrative regions and diverse ethnic zones were selected (Table 1, Figure 1) as follows: Kara region (7 villages), Central region (7 villages), Plateau region (13 villages) and Maritime region (13 villages). To study the local management of cassava diversity, 10 villages (in bold in Table 1) have been selected among the 40 previously investigated, based on the varietal diversity per ethnic group. 
Int.J.Curr.Microbiol.App.Sci (2017) 6(6): 3328-3340

Table.1 List of different villages surveyed in Togo

\begin{tabular}{|c|c|c|c|c|c|c|c|}
\hline No & Village & Canton & Prefecture & $\begin{array}{l}\text { Ethnic } \\
\text { group }\end{array}$ & Region & Latitude & Longitude \\
\hline 1 & Adjahun & Amlamé & Amou & Akposso & Plateaux & 7,48330 & 0,91660 \\
\hline 2 & Adokpoe & Agbelouvé & Zio & ewe & Maritime & 6,63330 & 1,18330 \\
\hline 3 & Afadonou & Tokpli & Yoto & ewe & Maritime & 6,63330 & 1,56660 \\
\hline 4 & Agbavé & Azanfiogbé & Agou & ewe & Plateaux & 6,75000 & 0,76660 \\
\hline 5 & Ahépé-Agbléta & Ahépé & Yoto & watchi & Maritime & 6,60000 & 1,41660 \\
\hline 6 & Aklakou & Aklakou & Lacs & mina & Maritime & 6,33330 & 1,71660 \\
\hline 7 & Akoumapé & Akoumapé & Vo & ewe & Maritime & 6,38720 & 1,44970 \\
\hline 8 & Akpakpakpé & Kpedomé & Haho & ewe & Plateaux & 7,11660 & 1,08330 \\
\hline 9 & Alhéridè & Alhéridè & Tchaoudjo & Tem & Centrale & 9,21660 & 1,20000 \\
\hline 10 & Atchavé & Atchavé & Haho & ewe & Plateaux & 6,86660 & 1,21660 \\
\hline 11 & Atikpaï & Kpessi & Est-mono & Ifè & Plateaux & 8,18330 & 1,31660 \\
\hline 12 & Ativeme & Bolou & Zio & ewe & Maritime & 6,42270 & 1,11050 \\
\hline 13 & Attikplè & Afagnan & Bas-Mono & watchi & Maritime & 6,46660 & 1,68330 \\
\hline 14 & Awounadjassi & Ahlon & Danyi & Ahlon & Plateaux & 7,33330 & 0,66660 \\
\hline 15 & Bagbé & Badja & Avé & ewe & Maritime & 6,33330 & 0,98330 \\
\hline 16 & Bounoh & Atchangbadè & Kozah & Kabyè & Kara & 9,48330 & 1,10000 \\
\hline 17 & Dalavé & Dalavé & Zio & ewe & Maritime & 6,38610 & 1,24860 \\
\hline 18 & Dôko & Zafi & Yoto & ewe & Maritime & 6,75000 & 1,33330 \\
\hline 19 & Doufouli & Doufouli & Blitta & Agnanga & Centrale & 8,31660 & 0,93330 \\
\hline 20 & Ganavé & Ganavé & Lacs & mina & Maritime & 6,30000 & 1,63330 \\
\hline 21 & Glitto & Glitto & Anié & Agouna & Plateaux & 7,58330 & 1,53330 \\
\hline 22 & Hometohoe & Tohoun & Moyen-mono & Adja & Plateaux & 7,00000 & 1,61660 \\
\hline 23 & Kamina & Kamina & Akébou & Akébou & Plateaux & 7,93330 & 0,85000 \\
\hline 24 & Kativou & Kpekpelemé & Moyen-mono & Adja & Plateaux & 7,26660 & 1,63330 \\
\hline 25 & Kpankpandja & Larini & Tchamba & Peulh & Centrale & 9,07278 & 1,41722 \\
\hline 26 & Kpaskpaï & Helota & Kéran & Lamba & Kara & 9,94320 & 0,80160 \\
\hline 27 & Lama-tessi & Lama-tessi & Tchaoudjo & Kabye & Centrale & 8,83330 & 1,08330 \\
\hline 28 & Mamakope & Kpélé-Nord & Kpélé & Kabyè & Plateaux & 7,20000 & 0,85000 \\
\hline 29 & Mome-Hounkpati & Mome & Vo & watchi & Maritime & 6,46660 & 1,56660 \\
\hline 30 & M'poti & M'poti & Blitta & Adélé & Centrale & 8,23330 & 0,76660 \\
\hline 31 & Natchamba & Bangeli & Bassar & bassar & Kara & 9,40000 & 0,58330 \\
\hline 32 & Niamgoulam & Titigbé & Sotouboua & Naouda & Centrale & 8,63500 & 1,09222 \\
\hline 33 & N'nababoun & Kabou & Bassar & lamba & Kara & 9,37000 & 0,81660 \\
\hline 34 & Otandjobo & Efoukpa & Wawa & Akposso & Plateaux & 7,58330 & 0,70000 \\
\hline 35 & Tipil & Kidjaboun & Dankpen & Konkomba & Kara & 9,71660 & 0,38330 \\
\hline 36 & Tomégbé & Kpimé & Kloto & ewe & Plateaux & 6,96660 & 0,65000 \\
\hline 37 & Vo-Afowuime & Vogan & Vo & watchi & Maritime & 6,36660 & 1,51660 \\
\hline 38 & Wargni & Djarkpanga & Plaine de Mô & Tem & Centrale & 8,78330 & 0,56660 \\
\hline 39 & Yaka & Léon & Doufelgou & lamba & Kara & 9,65000 & 0,95000 \\
\hline 40 & Yarayara & Daoudè & Assoli & Tem & Kara & 9,32900 & 1,07980 \\
\hline
\end{tabular}


Fig.1 Geographical location of the villages surveyed

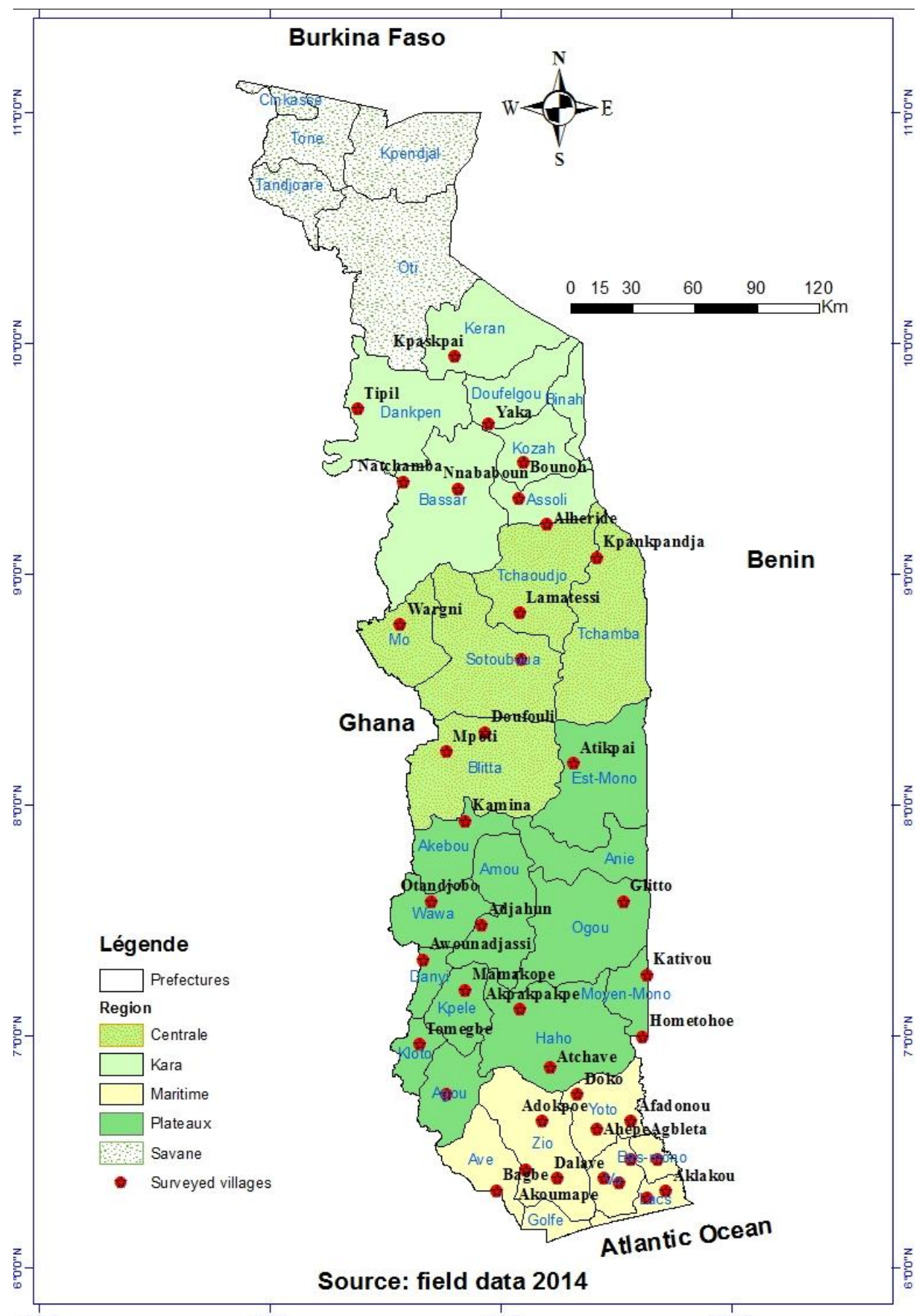

Data collection and analysis $\quad 20-30$ farmers (both men and women) of different ages with the help of translators

The first part of the survey was related to the production constraints and famers varieties preference criteria. In each of the surveyed sites, a group discussion was carried out with from each village. Local farmers' association, and extension workers were involved in the study to facilitate the organization of the meetings and the collection of data. 
The producers were asked to list by category and in their vernacular language all the constraints (abiotic and biotic) which hinder the production of cassava in their environment. The identified constraints were ranked in a group by the method of identification and progressive elimination of the most important constraint following Dansi et al., (2013). In a first step, producers were asked to identify, among the constraints they have listed, the most critical one and for which an urgent solution must be found.

The constraint thus identified is ranked first and is eliminated from the list. The same procedure was repeated until the last constraint was ranked and the results were given immediately to producers for approval. Later on, the producers always in group were brought to list the characteristics that a variety of cassava must have to be widely adopted in the context of their village. By using the same approach as that of the identification of the constraints, "progressive elimination of the most important criterion" was done.

The second part of the survey was the diversity management study. Here 10 households were selected using the method of transect described by Kombo et al., (2012). The households were chosen along transect (main alley crossing the village) and on both sides according to a fixed interval of five houses.

In every household, the interview took place with the head of the household or his wife or one of his wives in case of polygamy following (Loko et al., 2013a). The data were collected using semi-structured questionnaire including among others the germplasm exchange system, the storage practices and the preservation system, the knowledge of the producers on the sexual reproduction of the cassava and the way seeds and seedlings are handled, the choice of the potential conservation actors and the definition of their roles, the necessity or not to create village committees of conservation, the composition, functioning and activities of this committee when possible.

Data obtained were analyzed using descriptive statistics (average, percentage, etc.) and the results were presented in the form of tables. Per administrative region and at national levels, the national levels, the constraints were prioritized based on the methods of Loko et al., (2013) that used the average of the following three parameters:

- the total number of villages (TNV) in which the constraint was cited

- the number of villages in which the constraint was classified among the principal constraints (PCO) i.e. among the first five

- the number of villages where the constraint is the major one or ranked first (MAC)

For these three parameters, the higher the number, the more important the constraint. The importance of a constraint (IMC) was therefore determined by the formula:

$I M C=\frac{\mathrm{TNV}+\mathrm{PCO}+\mathrm{MAC}}{3}$.

The same approach was used to rank farmers' preference criteria.

\section{Results and Discussion}

\section{Importance of cassava in surveyed household}

In the 100 investigated households, 22 crops (Table 2) were quoted as cultivated. Cassava was quoted first main crop among all other crops. 
Int.J.Curr.Microbiol.App.Sci (2017) 6(6): 3328-3340

Table.2 Main crops in the study zone

\begin{tabular}{|c|c|c|c|c|c|c|c|c|}
\hline \multirow{2}{*}{ Crop } & \multicolumn{8}{|c|}{ Rank (\%) } \\
\hline & $1^{\text {st }}$ & $2^{\text {nd }}$ & $3^{\text {rd }}$ & $4^{\text {th }}$ & $5^{\text {th }}$ & $6^{\text {th }}$ & $7^{\text {th }}$ & Total \\
\hline Cassava & 45 & 21 & 10 & 10 & 3 & 2 & 1 & 92 \\
\hline Maize & 25 & 43 & 9 & 3 & 2 & 1 & 0 & 83 \\
\hline bean & 4 & 9 & 24 & 12 & 7 & 1 & 0 & 57 \\
\hline Yam & 2 & 3 & 12 & 12 & 3 & 2 & 0 & 34 \\
\hline Pepper & 5 & 2 & 6 & 2 & 2 & 0 & 0 & 17 \\
\hline Tomato & 4 & 4 & 5 & 3 & 0 & 1 & 0 & 17 \\
\hline Sorghum & 8 & 1 & 6 & 0 & 0 & 0 & 0 & 15 \\
\hline Rice & 2 & 4 & 3 & 2 & 3 & 1 & 0 & 15 \\
\hline Soya beans & 3 & 2 & 5 & 1 & 0 & 1 & 0 & 12 \\
\hline Groundnut & 1 & 2 & 1 & 4 & 1 & 0 & 0 & 9 \\
\hline Cotton & 3 & 1 & 3 & 1 & 0 & 0 & 0 & 8 \\
\hline Chorchorus & 2 & 2 & 0 & 2 & 1 & 1 & 0 & 8 \\
\hline Egusi* & 2 & 1 & 0 & 1 & 0 & 1 & 0 & 5 \\
\hline Okra & 2 & 2 & 0 & 0 & 0 & 0 & 0 & 4 \\
\hline Eggplant & 0 & 0 & 0 & 2 & 0 & 0 & 1 & 3 \\
\hline Millet & 0 & 1 & 0 & 1 & 0 & 0 & 0 & 2 \\
\hline Fonio & 0 & 0 & 0 & 0 & 1 & 1 & 0 & 2 \\
\hline Taro & 0 & 0 & 0 & 1 & 0 & 1 & 0 & 2 \\
\hline Banana & 0 & 0 & 1 & 0 & 0 & 0 & 0 & 1 \\
\hline Cashew tree & 0 & 0 & 0 & 0 & 0 & 0 & 1 & 1 \\
\hline Coffee & 0 & 0 & 0 & 1 & 0 & 0 & 0 & 1 \\
\hline Sweet potato & 0 & 0 & 0 & 1 & 0 & 0 & 0 & 1 \\
\hline
\end{tabular}

N.B. Egusi is seeds of cultivars coming from Citrullus lanatus subsp. Mucosospermus, Cucumeropsis mannii and Lagenaria siceraria species.

In the villages of Yarayara, Doufouli, M'poti, Ganavé and Momé-hounkpati, cassava is the main source of income crop (Table 3). Observations showed that in these villages, there are small home-made cassavas processing units installed here and there. In the village of Yaka, it is the sorghum which is the main cash income crop. In this village, cassava roots are transformed into dry chips mainly for the family consumption. Cassava dry chips are ground mixed with flour of maize, millet or sorghum to make the paste. In the remaining villages, every household has his main source of income crops. The storage of these harvested roots lasts mostly only three days. In some households, cassava and other crops are equal as main source of income. It is the example of 4 households in the village of Ganavé who besides the cassava as main culture also have maize and tomato at the same level.

\section{Constraints related to cassava cultivation in Togo}

The major constraints (the first 5 constraints) at the national level (Table 4) are: the attacks of insects, the lack of market, leaves and stem diseases, roots rot and lack of processing facilities. Only two major constraints (attacks of insects, leaves and stem diseases) are common to all the regions. In Kara region, roots rot is not a major constraint but rather the damages of animals in transhumance. In Central region, susceptibility of cassava chips to storage insects comes before the lack of processing facilities. In the Maritime region, soil poverty and climate variability were the major constraints. Among major constraints, attacks of insect is the first at national level and in the Maritime and Central region. 
Table.3 Main crops sources of income in the zone

\begin{tabular}{|c|c|c|c|c|c|c|c|c|c|c|c|}
\hline \multirow[b]{2}{*}{ Crops } & \multicolumn{11}{|c|}{ Villages } \\
\hline & Yaka & Yarayara & Doufouli & M'poti & Attikpaï & Adjahun & Kamina & Moméhounkpati & Ganavé & Ativémé & Total \\
\hline Cassava & & 10 & 10 & 10 & & 5 & 2 & 8 & 10 & 1 & 56 \\
\hline Maize & 1 & & & 2 & & & 4 & 4 & 1 & 4 & 16 \\
\hline Sorghum & 9 & & & & 1 & & & & & & 10 \\
\hline Soya bear & & & & & 3 & 1 & 3 & & & & 7 \\
\hline Rice & & & & & & & & 2 & & 3 & 5 \\
\hline Tomato & & & & & & 1 & & & 3 & 1 & 5 \\
\hline Cotton & & & & & 2 & & 3 & & & & 5 \\
\hline Pepper & & & & & 2 & & & & & 2 & 4 \\
\hline Egousi & & & & & 3 & & & & & & 3 \\
\hline Beans & & & & & & 3 & & & & & 3 \\
\hline Yams & & & & & 2 & & & & & & 2 \\
\hline Coffee & & & & & & 1 & & & & & 1 \\
\hline Groundnu & & & & & & & 1 & & & & 1 \\
\hline
\end{tabular}

Table.4 Cassava production constraints in Togo

\begin{tabular}{|c|c|c|c|c|c|c|c|c|c|}
\hline \multirow{2}{*}{ Constraints } & \multicolumn{3}{|c|}{ Number of villages } & \multirow[b]{2}{*}{$\mathrm{Av}$} & \multirow[b]{2}{*}{$\mathrm{Rn}$} & \multicolumn{4}{|c|}{ Rank per region } \\
\hline & TNV & $\mathrm{PC}$ & CMA & & & Mar & Pla & Cen & $\mathrm{Ka}$ \\
\hline Attacks of insects & 35 & 2 & 32 & 23 & 1 & 1 & 3 & 1 & 2 \\
\hline Lack of markets for selling & 28 & 13 & 24 & 21.7 & 2 & 6 & 1 & 1 & 1 \\
\hline Leaves and stem diseases & 32 & 3 & 25 & 20 & 3 & 2 & 4 & 1 & 5 \\
\hline Roots rot & 29 & 3 & 18 & 16.7 & 4 & 4 & 4 & 4 & 6 \\
\hline Lack of processing facilities & 22 & 4 & 19 & 15 & 5 & 11 & 2 & 6 & 2 \\
\hline Damages of animals in transhumance & 17 & 5 & 15 & 12.33 & 6 & 12 & 4 & 6 & 4 \\
\hline Soil poverty & 17 & 1 & 12 & 10 & 7 & 2 & 11 & & 7 \\
\hline Climate variability & 18 & 2 & 10 & 10 & 7 & 5 & 10 & 8 & 7 \\
\hline Susceptibility to weeds & 15 & 2 & 9 & 8.7 & 9 & 9 & 7 & 8 & 8 \\
\hline Lack of cutting & 11 & 2 & 8 & 7 & 10 & 8 & 9 & 12 & 11 \\
\hline Lack of early maturing varieties & 13 & 1 & 7 & 7 & 10 & 6 & 7 & - & - \\
\hline Susceptibility to high soil & 6 & 1 & 3 & 3.3 & 12 & 14 & 11 & 10 & - \\
\hline Susceptibility of chips to storage insects & 5 & 0 & 4 & 3 & 13 & - & - & 5 & 11 \\
\hline $\begin{array}{l}\text { Bad in ground post maturity storage } \\
\text { ability }\end{array}$ & 6 & 0 & 2 & 2.7 & 14 & 16 & 13 & 12 & 11 \\
\hline Other attacks on root & 5 & 0 & 2 & 2.3 & 15 & 12 & 15 & - & 8 \\
\hline Inadaptability to all types of soil & 5 & 0 & 2 & 2.3 & 15 & 16 & 13 & 12 & - \\
\hline Fast post-harvest drying of stems & 5 & 0 & 2 & 2.3 & 15 & 10 & 15 & - & - \\
\hline Damage of bush fire on cassava fields & 4 & 0 & 1 & 1.7 & 18 & - & 17 & 10 & 11 \\
\hline
\end{tabular}

NB: TNV: Total Number of villages where this constraint has been listed; PC: Principal Constraint; MAC: Major Constraints, Av: Average; Rn: Rank at national level 
The impact of this climate variability (Table 4) is less felt in Plateau region and is ranked 5th in the Maritime region and $7^{\text {th }}$ at national level and in Kara region. The absence of market comes in the second position at the national level while it is ranked sixth in Maritime Region and first in the three remaining regions. The damages of animals in transhumance and the lack of processing facilities are less marked in the maritime region which is more provided in processing equipment than the others. In Central and Kara regions, apart from fufu, cassava roots are transformed into dry chips. In this region, susceptibility of dry chips to weevils was quoted as constraints.

This study on production constraints, famers' preference criteria and diversity management of local cassava varieties is the first one carried out in Togo. Among major constraints, the attacks of insects occupy the first rank at national level and in the Maritime and Central regions which are less watered and where cassava last during dry season. The absence of cochineal in West-Plateau where the impacts of climate variability are less felt confirms that the attacks of these insects are closely linked to the climate variability. The absence of market is not a major constraint in Maritime region where the international market of Lomé is located. According to Akinnagbe, (2010) there is a high demand for cassava raw materials for agro-industries. About diseases, Banito et al. (2007) reported that cassava bacterial blight and cassava mosaic disease have relatively high importance in all the ecological zones of Togo. Research has to release cassava varieties that are resistant or tolerant to diseases in all the country.

\section{Famers' preference criteria}

Twenty (20) preference criteria were identified throughout the surveyed villages (Table 5). Among them, six (6) were of culinary and technological (good quality of crazy, good quality of the gari, high yielding in gari, good taste, good quality of tapioca, high starch content) nature while 14 were of agronomic type. In the entire study area, the top five preference are high productivity, precocity, good quality of fufu, resistance to diseases, and good quality of gari. High productivity is not a main concern in the Maritime and Plateau regions while it is important in Central and Kara Regions. In the Maritime region, resistance to drought is among the major criteria. Drought tolerant varieties are needed to face the periods of irregularity of rains.

All the regions have specificities with regard to the $5^{\text {th }}$ preference criterion. The producers of Maritime region were looking for varieties adapted to less fertile soils. Those of Plateau wish to obtain resistant varieties to root rot while those of Central region prefer varieties adapted to all types of soil. All these preferences seem to be solutions to the enumerated constraints. In the Kara region resistance of chips to storage insects and good quality of the tapioca surprisingly appeared. Most probably, population of this zone wishes to transform cassava into chips and tapioca but they lack processing equipment $\left(2^{\text {nd }}\right.$ constraint within this region).

Farmers' preference criteria and their ranking indicate that high productive and early growing cassava varieties are those needed for near future. Our respondents showed huge interest in increasing cassava yields by using high productive and early maturing cassava varieties. Late maturing and low productive local varieties may be abandoned if no culture or no food habit support their cultivation. It is urgent to undertake preservation strategies. These findings do not match those of PeñaVenegas et al. (2014) who reported no preference in increasing cassava yields in five ethnic groups of the Colombian Amazon. High yielding, early maturity, good quality of 
fufu, resistance to diseases and good quality of gari were the top most important. Similar to the studies on the diversity of yams (Dansi et al. 2013), high productivity as major criterion is not surprising since it is for any producer and any crop the most desired criterion. It is not also surprising to see precocity occupying the second rank because high productivity associated to earliness increases the production of the cultures in short time. These results also partially confirm those obtain by Kombo et al. (2012) at Bouenza (Republic of Congo) where, among the twenty (20) preference criteria considered by the farmers when making a choice, high yield, early maturity and taste were the top most important. In the preferences criteria, producers put in $3^{\text {rd }}$ position the resistance of the varieties to diseases. It is to say that these diseases reduce highly the productivity. Producers understood that increase of productivity depends on the performance of the varieties but also on their resistance to diseases.

Table.5 Farmers' preference criteria of cassava varieties and their importance across regions

\begin{tabular}{|c|c|c|c|c|c|c|c|c|c|}
\hline \multirow[t]{2}{*}{ Preference criteria } & \multicolumn{3}{|c|}{ Number of villages } & \multirow[b]{2}{*}{ Av } & \multirow[b]{2}{*}{$\mathrm{Rn}$} & \multicolumn{4}{|c|}{ Rank per region } \\
\hline & TNV & $\mathrm{PCr}$ & MAC & & & Mar & Plat & Cen & Kar \\
\hline High productivity & 38 & 11 & 33 & 27.3 & 1 & 2 & 2 & 1 & 1 \\
\hline Precocity & 31 & 14 & 30 & 25 & 2 & 1 & 1 & 3 & 3 \\
\hline Good quality of fufu & 28 & 2 & 26 & 18.7 & 3 & 3 & 3 & 4 & 9 \\
\hline Resistance to diseases & 21 & 2 & 16 & 13 & 4 & 3 & 6 & 9 & 3 \\
\hline Good quality of gari & 21 & 1 & 14 & 12 & 5 & 7 & 4 & 7 & 10 \\
\hline Non toxicity & 16 & 5 & 12 & 11 & 6 & 13 & 7 & 2 & 2 \\
\hline $\begin{array}{l}\text { Adaptability to all type of } \\
\text { soils }\end{array}$ & 10 & 0 & 9 & 6.3 & 7 & 16 & 13 & 5 & 7 \\
\hline Resistance to drought & 11 & 0 & 7 & 6 & 8 & 5 & 14 & 14 & 10 \\
\hline High productivity in gari & 11 & 1 & 6 & 6 & 8 & 8 & 7 & 14 & 14 \\
\hline $\begin{array}{l}\text { Tolerance to high soil } \\
\text { moisture }\end{array}$ & 9 & 1 & 7 & 5.7 & 10 & 8 & 9 & 9 & - \\
\hline Resistance to weeds & 10 & 1 & 6 & 5.7 & 10 & 13 & 17 & 6 & 7 \\
\hline Resistance to root rot & 9 & 1 & 7 & 5.7 & 10 & - & 5 & 8 & 10 \\
\hline Adaptability to poor soils & 8 & 1 & 7 & 5.3 & 13 & 5 & - & 12 & - \\
\hline Good taste & 7 & 0 & 5 & 4 & 14 & 10 & 14 & 14 & 14 \\
\hline Good quality of tapioca & 10 & 0 & 2 & 4 & 14 & 10 & 11 & 9 & 5 \\
\hline Good quality of dry chips & 5 & 0 & 4 & 3 & 16 & 10 & 11 & 14 & - \\
\hline $\begin{array}{l}\text { Resistance of chips to } \\
\text { storage insects }\end{array}$ & 4 & 2 & 3 & 3 & 16 & - & - & 12 & 5 \\
\hline High content in starch & 6 & 0 & 2 & 2.7 & 18 & 13 & 14 & - & 13 \\
\hline $\begin{array}{l}\text { Good storage of the } \\
\text { cuttings }\end{array}$ & 4 & 0 & 2 & 2 & 19 & 17 & 9 & - & - \\
\hline $\begin{array}{l}\text { Good in ground post } \\
\text { maturity conservation }\end{array}$ & 2 & 0 & 0 & 0.7 & 20 & 17 & - & 14 & - \\
\hline
\end{tabular}

NB: TNVC: total number of villages where criteria have been identified; PCr: Principal criteria; MAC: major Criteria; Av: Average; Rn: Rank at national level 
Farmers' knowledge, use and management of cassava sexual propagation

Among the 100 investigated households, 87 have seen flowers and seeds of some cassava varieties but they don't use the seeds. Only $22 \%$ of the interviewees have seen seedlings and reported that they produce only a single root. However, they do not attach any importance to those seedlings and even destroy them some time during weeding. According to farmers, only cassava plants that produce branch have flowers. One farmer from Dalavé village reported during group discussion that he used cutting from seedling that emerged from seeds in his farm and named the landrace with his own name for traceability (i.e. Aladevi).

Cassava has a huge importance for Togolese's farmers as their main food and cash income crop. Changes are occurring in the decisionmaking processes that determine crop diversity by the replacement of traditional crops. Cassava seedlings are also source of diversity variability (Kawuki et al. 2013) from which new landraces can arise, apart from mutation which this study did not examine. Contrary to the report of Fraser et al. (2012), Peña-Venegas et al. (2014), although cassava seeds and seedlings appeared to be wellknown to some Togolese farmers, few farmer use them. But all the farmers who have seen seedlings recognized that seedlings are plants that do not grow from stem cuttings, produce only a single bulking root, and are morphologically different from the planted landraces, as they tend to grow taller and only have a single tuberous root growing straight downwards (Fraser et al, 2012, Peña-Venegas et al. 2014). In this traditional agriculture, cassava is usually propagated by means of stem cuttings (Kombo et al. 2012; Turyagyenda et al. 2012). Same as the studies of Manu-Aduening et al. (2005), none of all the interviewed farmers understood the role of pollination in seeds setting and providing variation amongst seedlings, none purposely planted seeds and most farmers ignored or weeded out cassava seedlings. Since the input supply is scarce, the only way to raise the level of production is undoubtedly improved genetic potential of cassava (Adjata et al. 2013). Communication and capacity building is therefore required for farmers as mentioned by Kombo et al. (2012).

\section{Diversity management}

In each of the investigated households, several modes of obtaining cuttings and new varieties were reported (Table 6 and 7). According to the producers, acquisition of new varieties (Table 6) within household is made by gift (53.6\%) of some cuttings. These cuttings are then planted in fields, tested and multiplied if they present interesting characters. The acquisition of new varieties (Table 6) by purchase and exchanges between farmers represent respectively $25.2 \%$ and $12.3 \%$. Inheritance of variety is rarely observed $(6.5 \%)$.

Table.6 New varieties access mode

\begin{tabular}{llllll}
\hline \multirow{2}{*}{ Mode } & \multicolumn{4}{c}{ Relative frequency per region (\%) } & \multirow{2}{*}{ Study zone } \\
\cline { 2 - 6 } & Kara & Centrale & Plateaux & Maritime & \\
\hline Gift & 5.7 & 7.3 & 22.0 & 18.7 & 53.6 \\
Purchase & 2.4 & 4.8 & 4.0 & 13.8 & 25.2 \\
Exchange & 4.8 & 6.6 & 0.9 & 0.0 & 12.3 \\
Inheritance & 4.9 & 0.0 & 1.6 & 0.0 & 6.5 \\
Introduction by agricultural extension & 2.4 & 0.0 & 0.0 & 0.0 & 2.4 \\
\hline
\end{tabular}


The introduction by agricultural institutions (2.4\%) was quoted only in the region of Kara. The introduction from the nearby country, was mentioned in none of the households as mode of obtaining cutting. In each of the investigated households, several modes of obtaining of cuttings were indicated (Table 7). The majority $(48.1 \%)$ of cuttings used in their fields come from previous cassava crops of the previous field. Obtaining of cuttings is also made by gift (35.3\% of answer) and by purchase $(16.6 \%)$. Farmer added that, gifts, exchange and inheritance occurs between relatives, neighbors or friends, usually within the same ethnic group.

Table.7 Cutting obtainment modes

\begin{tabular}{|c|c|c|c|c|c|}
\hline \multirow{2}{*}{ Mode } & \multicolumn{4}{|c|}{ Relative frequency per region (\%) } & \multirow{2}{*}{$\begin{array}{l}\text { Study } \\
\text { zone }\end{array}$} \\
\hline & Kara & Centrale & Plateaux & Maritime & \\
\hline Retention from previous field & 10.1 & 10.1 & 12.3 & 15.5 & 48.1 \\
\hline Gift & 3.8 & 4.8 & 14.4 & 12.3 & 35.3 \\
\hline Purchase & 1.6 & 3.2 & 2.6 & 9.1 & 16.6 \\
\hline
\end{tabular}

The introduction from the nearby countries has been mentioned in none of the households as the mode of obtaining cutting.

In the investigated villages, there was neither an association of seed production nor varieties diversity preservation community fields. About $85 \%$ of the investigated households agreed that it was adequate to have diversity preservation community fields on public lands. The maintenance of such fields should be made by rotation of the group's members and cuttings (planting materials) produced will be sold.

Most Togolese farmers obtained their cassava planting material either from their own fields or from within their community. This is similar to the results reported by Samberg et al., (2013) in the southern highlands of Ethiopia and Manu-Aduening et al., (2005) in Ghana. Contrary to the study of PeñaVenegas et al., (2014) in Colombian Amazon, there is no use of different manioc landraces by Togolese farmers to create differences between ethnic groups. Farmers seem to take any opportunity they can to exchange seeds with their friends and relatives when they observe a good variety (Carpenter, 2005).
Access to cutting through inheritance is low (6.5\%), farmers are not waiting for their parents to die before cultivating their own farms. So, they get varieties through donation and until their relatives die, they have the same varieties in their own farm. According to Emperaire and Peroni, (2007) and PeñaVenegas et al., (2014) role of women is essential in the circulation of cassava diversity.

The whole study reveals that farmers have so far utilized and maintained a great diversity of cassava varieties, but constraints, and farmers preferences are challenging with cultural aspects, eating habit for this diversity maintenance or its erosion. It also reveals that the best way to increase cassava production is not only that research must release a lot of varieties according to the desire of famers, but this research has also to increase the diversity preservation issues and to work closely with policy makers for market availability of cassava. If the many socioeconomic constraints on cassava production, utilization, and marketing could be alleviated, farmers' yields could be easily doubled by using improved technologies (El-Sharkawy, 2004). 


\section{Conflict of interest statement}

Authors declare that they have no conflict of interest.

\section{Acknowledgment}

This study was sponsored by the Togo component of the West African Agricultural Productivity Program (WAAPP) on request of the National Agricultural Research Institute (ITRA) and UEMOA through PAES program. We express our gratitude to the national institute of agricultural extension for technical support and to the farmers we met for fruitful discussion.

\section{References}

Adjata, K.D., Tchaniley, L., Banla, E., Tchansi, K.K., Gumedzoe, Y.M.D. 2013. Study of germination conditions of cassava (Manihot esculenta Crantz) seeds obtained by genetic selection. Scientific Res. Essays, 8(43), pp. 2138-2143.

Akinnagbe, O.M. 2010. Constraints and strategies towards improving cassava production and processing in Enugu North Agricultural Zone of Enugu State, Nigeria. Bangladesh J. Agric. Res., 35: 387-394.

Banito, A., Verdier, V., Kpémoua, K.E., Wydra, K. 2007. Assessment of major cassava diseases in Togo in relation to agronomic and environmental characteristics in a systems approach. Afr. J. Agric. Res., 2: 418-428.

Bull, S.E., Ndunguru, J., Gruissem, W., Beeching, J.R., Vanderschuren, H. 2011. Cassava: constraints to production and the transfer of biotechnology to African laboratories. Plant Cell Rep., 30: 779787.

Carpenter, D. 2005. The in situ conservation of rice plant genetic diversity: a case study from a Philippine Barangay. Agric. Hum. Values, 22: 421-434.

Country STAT. 2014. Répartition de la production des cultures primaires.

Dansi, A., Dantsey-Barry, H., Agre, A.P., Dossou-Aminon, I., Assogba, P., Loko, Y.L., N'Kpenu, E.K., Kombaté, K., Dansi, M., Vodouhè, R. 2013. Production constraints and farmers' cultivar preference criteria of cultivated yams (Dioscorea cayenensis - D. rotundata complex) in Togo. Int. J. Appl. Biol. Pharma. Technol., 4(2): 191-199.

De Oliveira, E.J., Ferreira, C.F., da Silva Santos, V., de Jesus, O.N., Oliveira, G.A.F., and da Silva, M.S. 2014. Potential of SNP markers for the characterization of Brazilian cassava germplasm. Theor. Appl. Genet., 127: 1423-1440.

DGSCN. 2011. Recensement général de la population et de l'habitat.

El-Sharkawy, M. 2004. Cassava biology and physiology. Plant Mol. Biol., 56: 481501.

Emperaire, L., Peroni, N. 2007. Traditional management of agrobiodiversity in Brazil: a case study of manioc. Hum. Ecol., 35: 761-768.

Fraser, J.A., Alves-Pereira, A., Junqueira, A.B., Peroni, N., Clement, C.R. 2012. Convergent adaptations: bitter manioc cultivation systems in fertile anthropogenic dark earths and floodplain soils in Central Amazonia. PLoS One, 7: e43636.

Jarvis, A., Ramirez-Villegas, J., Campo, B.V.H., Navarro-Racines, C. 2012. Is cassava the answer to African climate change adaptation? Trop. Plant Biol., 5: 9-29.

Kawuki, R.S., Herselman, L., Labuschagne, M.T., Nzuki, I., Ralimanana, I., Bidiaka, M., Kanyange, M.C., Gashaka, G., Masumba, E., Mkamilo, G., Gethi, J. 2013. Genetic diversity of cassava (Manihot esculenta Crantz) landraces and cultivars from southern, eastern and central Africa. Plant Genetic Res., 11(2), pp.170-181.

Kombate, K., Dansi, A., Dossou-Aminon, I., Adjatin, A., Kpemoua, K., Dansi, M., 
Akpagana, K., Sanni, A. 2017. Diversity of Cassava (Manihot esculenta Crantz) Cultivars in the Traditional Agriculture of Togo. Int. J. Curr. Res. Biosci. Plant Biol., 4: 98-113.

Kombo, G.R., Dansi, A., Loko, L.Y., Orkwor, G.C., Vodouhè, R., Assogba, P., Magema, J.M. 2012. Diversity of cassava (Manihot esculenta Crantz) cultivars and its management in the department of Bouenza in the Republic of Congo. Genet. Resour. Crop Evol., 59: 17891803.

Lebot, V., Malapa, R., Sardos, J. 2015. Farmers' selection of quality traits in cassava (Manihot esculenta Crantz) landraces from Vanuatu. Genet. Resour. Crop Evol., 62: 1055-1068.

Loko, Y.L., Dansi, A., Dansi, M., Vodouhè, R., Sanni, A. 2013. Indigenous Knowledge and Management of Yam (Dioscorea Cayenensis-Dioscorea Rotundata Complex) Pests and Diseases in Northern Benin. Int. J. Appl. Biol. P. T, pp: 277287.

Loko, Y.L., Dansi, A., Tamo, M., BokononGanta, A.H., Assogba, P., Dansi, M., Vodouhè, R., Akoegninou, A., Sanni, A. 2013a. Storage insects on yam chips and their traditional management in Northern Benin. Sci. World J., pp: 1-12.

Manu-Aduening, J.A., Lamboll, R.I., Dankyi, A.A., Gibson, R.W. 2005. Cassava diversity in Ghanaian farming systems. Euphytica, 144: 331-340.

Peña-Venegas, C.P., Stomph, T.J., Verschoor, G., Lopez-Lavalle, L.A.B., Struik, P.C. 2014. Differences in manioc diversity among five ethnic groups of the Colombian Amazon. Diversity, 6: 792826.

Samberg, L.H., Shennan, C., Zavaleta, E. 2013. Farmer seed exchange and crop diversity in a changing agricultural landscape in the southern highlands of Ethiopia. Hum. Ecol., 41: 477.

Thomas, M., Dawson, J.C., Goldringer, I., Bonneuil, C. 2011. Seed exchanges, a key to analyze crop diversity dynamics in farmer-led on-farm conservation. Genet. Resour. Crop Evol., 58: 321-338.

Turyagyenda, L.F., Kizito, E.B., Ferguson, M.E., Baguma, Y., Harvey, J.W., Gibson, P., Wanjala, B.W., Osiru, D.S.O. 2012. Genetic diversity among farmer-preferred cassava landraces in Uganda. Afr. Crop Sci. J., 20.

\section{How to cite this article:}

Kombate, K., I. Dossou-Aminon, A. Dansi, R.A. Adjatin, G.A. Dassou, K. Kpemoua, M. Dansi, K. Akpagana and Sanni, A. 2017. Cassava (Manihot esculenta Crantz) Production Constraints, Farmers' Preference Criteria and Diversity Management in Togo. Int.J.Curr.Microbiol.App.Sci. 6(6): 3328-3340. doi: https://doi.org/10.20546/ijcmas.2017.606.391 